Article

\title{
Effects of Calcium Soaps from Palm, Canola and Safflower Oils on Dry Matter Intake, Nutrient Digestibility, Milk Production, and Milk Composition in Dairy Goats
}

\author{
Einar Vargas-Bello-Pérez ${ }^{1, * \mathbb{D}}$, Lizbeth Esmeralda Robles-Jimenez ${ }^{2}$, Rafael Ayala-Hernández ${ }^{2}$, \\ Jose Romero-Bernal ${ }^{2}$, Nazario Pescador-Salas ${ }^{2}$, Octavio Alonso Castelán-Ortega ${ }^{2}$ (D) and \\ Manuel González-Ronquillo 2,*iD \\ 1 Department of Veterinary and Animal Sciences, Faculty of Health and Medical Sciences, \\ University of Copenhagen, Grønnegårdsvej 3, DK-1870 Frederiksberg C, Denmark \\ 2 Facultad de Medicina Veterinaria y Zootecnia, Universidad Autónoma del Estado de México, \\ Instituto Literario 100, CP 50000 Toluca, Mexico; lizroblez@hotmail.com (L.E.R.-J.); \\ elpipilaenmadison@yahoo.com (R.A.-H.); gazapo79@yahoo.com.mx (J.R.-B.); \\ npescadors@uaemex.mx (N.P.-S.); oacastelano@uaemex.mx (O.A.C.-O.) \\ * Correspondence: evargasb@sund.ku.dk (E.V.-B.-P.); mrg@uaemex.mx (M.G.-R.)
}

Received: 2 July 2020; Accepted: 18 September 2020; Published: 23 September 2020

Simple Summary: Dietary fats can increase energy density in dairy goat diets. However, dietary fats are subject to changes in rumen that affect nutrient intake and digestibility and milk production. In order to by-pass rumen degradation, one strategy is to protect those fats by saponification, which results in calcium soaps of fatty acids. Thus, this study determined the effect of calcium soaps of either palm (PO), canola (CO) or safflower (SO) oils on dry matter intake, digestibility and milk production in dairy goats. Compared with $\mathrm{PO}$ and $\mathrm{CO}$, milk production increased with $\mathrm{SO}$, while $\mathrm{CO}$ was more digestible. Compared to calcium soaps from $\mathrm{PO}, \mathrm{SO}$ resulted in increased milk yield without negative effects on digestibility and nutrient intake. Overall, compared with the traditional use of calcium soaps manufactured from $\mathrm{PO}$, at an inclusion of $2.7 \%$ dry matter, calcium soaps of $\mathrm{SO}$ can be used in goat diets to increase milk production, milk protein and milk fat yields without negative effects on nutrient intake and digestibility.

\begin{abstract}
This study determined the effect of protected dietary oils on dry matter intake (DMI), digestibility and milk production in dairy goats. Nine Saanen goats were used in a $3 \times 3$ Latin square design with three periods of 25 days. A basal diet based on barley hay and corn silage was supplemented with $2.7 \%$ DM of calcium soaps of either palm (PO), canola (CO) or safflower (SO) oils. Data for dry matter intake, nutrient digestibility and milk production was analyzed using the general linear model (GLM) procedure of SAS. Gas production data was analyzed using the procedure of non-linear regression analysis (PROC NLIN) from SAS. Nutrient intakes were not affected by treatments. However, compared with CO, the digestibility of dry matter (653 vs. 552 and $588 \mathrm{~g} / \mathrm{kg}$ ), organic matter (663 vs. 559 and $606 \mathrm{~g} / \mathrm{kg}$ ) and neutral detergent fiber (616 vs. 460 and $510 \mathrm{~g} / \mathrm{kg}$ ) were lowered $(p<0.001)$ by SO and PO. Compared with $\mathrm{CO}$, in vitro gas production increased $(p<0.001)$ in PO and SO (174 vs. 201 and $206 \mathrm{~mL}$ gas/g incubated DM). Compared with PO and CO, milk production increased $(p<0.001)$ with $\mathrm{SO}(0.88$ and $0.95 \mathrm{vs} .1 .10 \mathrm{~kg} / \mathrm{d}$, respectively). With regard to $\mathrm{PO}$ and $\mathrm{SO}, \mathrm{CO}$ decreased fat ( 34 and 35 vs. $32 \mathrm{~g} / \mathrm{d}$ ) and protein ( 35 and $38 \mathrm{vs.} 30 \mathrm{~g} / \mathrm{d}$ ) in milk. In conclusion, compared to the traditional use of calcium soaps manufactured from $\mathrm{PO}$, protected $\mathrm{SO}$ resulted in increased milk yield without negative effects on digestibility and nutrient intake.
\end{abstract}


Keywords: calcium soaps; goats; canola oil; safflower oil; nutrient digestibility

\section{Introduction}

The use of different types and levels of fat in the diet has major effects on the quantity and composition of milk from goats and sheep [1]. The palm oil (PO) industry produces several by-products (i.e., palm oil, palm press fiber, palm kernel cake and palm oil decanter cake) that represent alternatives for feeding ruminants [2]. Their inclusion in diets can be an effective measure in overcoming the lack of grazing pasture for goats and sheep. On the other hand, in the past decade, the production of canola oil (CO) has increased, and is available at a reasonable cost. CO by-products, such as crude canola oil, can thus provide an alternative to the use of $\mathrm{PO}$ in small ruminants [3]. In fact, the blend of PO and $\mathrm{CO}$ has been reported to increase polyunsaturated fatty acids (PUFA) in muscle without having detrimental effects on nutrient intake and digestibility and growth performance in goats [4].

In dairy goats, adding safflower oil (SO) at $50 \mathrm{~g} / \mathrm{kg}$ dry matter (DM) to goat diets based on chopped alfalfa hay has been shown to be an effective strategy to increase milk PUFA without detrimental effects on feed intake and milk production [5]. The intake of lipids in the form of protected fats allows the increase of fatty acids (FA) available for intestinal absorption [6], without causing negative effects on the ruminal microbial population and feed digestibility [7]. The use of various lipid supplements in goats, such as calcium soaps, can increase milk production, modify the percentage of milk fat and produce changes in the milk FA profile [8].

Calcium soaps based on different vegetable oils have been used in ruminant production; for example, feeding calcium soaps of palm oil has been shown to increase milk fat in early lactating ewes $[9,10]$ and increase feed conversion ratio without affecting carcass yield in growing lambs [11]. On the other hand, calcium soaps from canola, soybean and linseed oils have been used to increase milk PUFA in cows [12]. In ewes, safflower oil has been used as a feeding strategy to improve milk production and increase the contents of PUFA in milk [13]. However, information on calcium soaps of safflower oil in goat diets is not available.

It is known that in small ruminants, the degree of FA saturation of lipid sources will influence animal performance [3], milk composition [14] and milk FA profile [15,16]. In fact, in goat mammary epithelial cells, saturated and unsaturated long-chain FAs exert differential expression of genes related to lipid metabolism [17]. To our knowledge, no research has been done to study the concurrent benefits of feeding calcium soaps of $\mathrm{CO}$ or $\mathrm{SO}$ on nutrient digestibility and productive traits in dairy goats, as opposed to the more traditional use of calcium soaps manufactured from PO [18]. Thus, the objective of the present study was to evaluate three sources of protected oils (calcium soaps) as an energy supplement in dairy goats and to assess the effects of protected dietary oils on dry matter intake, nutrient digestibility, milk production and milk composition in dairy goats. To this end, calcium soaps of either palm oil, canola oil or safflower oil were used. The hypothesis of this study was that nutrient digestibility, milk production and milk composition are affected differentially by the degree of FA saturation of dietary lipids, with palm oil being a saturated FA source and canola and safflower oils being unsaturated FA sources. In this study, the reference condition (control diet) was calcium soap from palm oil, as it is the most common protected oil available in the Mexican market.

\section{Materials and Methods}

\subsection{Animals, Experimental Design and Diets}

The present study was carried out in the Animal Science farm of the School of Veterinary Medicine and Animal Science of the Universidad Autónoma del Estado de México. All animal studies were conducted according to the Animal Care and Use Committee of Veterinary and Animal Science from Universidad Autónoma del Estado de México (Toluca, Mexico) (Project ID UAEMex 3060-2011). 
Nine Saanen goats [ $51 \pm 0.4 \mathrm{~kg}$ of body weight; $19.1 \pm 0.02$ metabolic live weight $\left.\left(\mathrm{LW}^{0.75}\right)\right]$ were used in a $3 \times 3$ Latin square design with three periods of 25 days consisting of 20 days for adaptation followed by 5 days of sampling. At the beginning of the study, all animals had $160 \mathrm{~d}$ of lactation. A basal diet based on barley hay and corn silage was supplemented with 2.7\% DM of calcium soaps of either palm (PO; Megalac- $\mathrm{R}^{\circledR}$, Arm \& Hammer Animal Nutrition, Princenton, NJ, USA), canola (CO) or safflower (SO) oils. Calcium salts of $\mathrm{PO}$ were considered as the reference condition (control). The chemical composition of individual feedstuffs and lipid supplements used in the experimental diets is shown in Table 1.

Table 1. Chemical composition ( $\mathrm{g} / \mathrm{kg}$ dry matter (DM)) of individual feedstuffs and lipid supplements used in the experimental diets.

\begin{tabular}{ccccccccc}
\hline Ingredient $^{1}$ & DM & CP & EE & NDF & ADF & Ca & P & ME $^{3}$ \\
\hline Soybean meal & 900 & 440 & 17 & 161 & 80 & 3 & 7 & 12.9 \\
Barley hay & 880 & 120 & 20 & 650 & 370 & 1 & 4 & 8.8 \\
Corn grain & 900 & 80 & 41 & 145 & 26 & 1 & 3 & 14.5 \\
Corn silage & 387 & 68 & 30 & 550 & 300 & 2 & 2 & 10.9 \\
Calcium soaps of palm oil & 972 & 0 & 848 & 0 & 0 & 18 & 0 & 26.8 \\
Calcium soaps of canola oil & 969 & 0 & 840 & 0 & 0 & 18 & 0 & 25.8 \\
Calcium soaps of safflower oil $^{3}$ & 970 & 0 & 845 & 0 & 0 & 18 & 0 & 26.4 \\
Vitamin and mineral premix $^{2}$ & 1000 & 0 & 0 & 0 & 0 & 4.5 & 0.14 & 0 \\
\hline
\end{tabular}

${ }^{1} \mathrm{DM}=$ Dry matter; $\mathrm{CP}=$ crude protein; $\mathrm{EE}$ = ether extract; $\mathrm{NDF}=$ neutral detergent fiber; $\mathrm{ADF}=$ acid detergent fiber; $\mathrm{ME}=$ metabolizable energy $(\mathrm{MJ} / \mathrm{kg} \mathrm{DM}) .{ }^{2}$ Containing in $1.0 \mathrm{~kg}$ DM the following: $25 \mathrm{mg}$ of antioxidant, $4.5 \mathrm{~g}$ of calcium carbonate, $6 \mathrm{~g}$ of salt, $30 \mathrm{~g}$ of ionophore, $50 \mathrm{~g}$ of zinc oxide, $6 \mathrm{~g}$ of sodium bicarbonate, $6 \mathrm{~g}$ of copper sulphate, $20 \mathrm{~g}$ of ferrous sulphate, $125 \mathrm{~g}$ of sodium sulphate, 18,000 IU of vitamin E, 3,000,000 UI of vitamin A, $3,750,000 \mathrm{IU}$ of vitamin D, $140 \mathrm{~g}$ of potassium chloride, $0.500 \mathrm{~g}$ of EDD. I ethylene-dynamine, $0.090 \mathrm{~g}$ of cobalt carbonate, $500 \mathrm{mg}$ of magnesium oxide, $36 \mathrm{~g}$ of manganese oxide and $0.090 \mathrm{~g}$ of selenium. ${ }^{3}$ Calculated from the National Research Council [19].

The basal diet consisted of forage (barley hay and corn silage) and concentrate (cracked corn grain and soybean meal) supplemented with vitamins and minerals (Multitec of Malta ${ }^{\circledR}$, Celaya Guanajuato, Mexico). Dietary treatments (Table 2) were formulated to be iso-proteic and iso-energetic $(111 \mathrm{~g} \mathrm{CP} / \mathrm{d}$ and $12 \mathrm{MJ} \mathrm{ME/d)} \mathrm{[19].} \mathrm{Diets} \mathrm{were} \mathrm{offered} \mathrm{as} \mathrm{total} \mathrm{mixed} \mathrm{rations} \mathrm{and} \mathrm{calcium} \mathrm{soaps} \mathrm{of} \mathrm{PO,} \mathrm{CO} \mathrm{and} \mathrm{SO}$ were mixed manually at each individual feed bunk. Animals were kept in individual metabolic cages $(1.20 \times 0.80 \mathrm{~m})$ with free access to water. Dietary treatments were divided into two meals and were offered daily at 08:00 and 16:00 $\mathrm{h}$.

Feed intake, amount of feces and urine were recorded daily, but only measurements collected during the last five days of each experimental period were used for statistical analysis. Individual samples of feed, feces and urine were collected at 08:00 h during the last five days of each experimental period and then frozen at $-20{ }^{\circ} \mathrm{C}$ until further analysis. For feces and urine, only $10 \%$ of the total sample collected was used for analysis.

Feces and urine samples were used to determine $\mathrm{N}$ intake and excretion. Urine $\mathrm{N}$ was analyzed using micro-Kjeldahl analysis. For feces, dry matter (DM; 930.15), organic matter (OM; 942.05) and nitrogen ( $\mathrm{N}$; 990.02) were determined using the Association of Official Analytical Chemists [20] methods, while neutral detergent fiber (NDF) and acid detergent fiber (ADF) were determined following Van Soest et al. [21] methods with alpha amylase and uncorrected ash content. Individual body weights (BW) were measured at the beginning and end of each experimental period. 
Table 2. Ingredients and chemical composition of safflower oil (SO), canola oil (CO) and palm oil (PO) treatments in dairy goat diets.

\begin{tabular}{cccc}
\hline Parameters & SO & CO & PO \\
\hline Ingredients, g/kg DM & & \\
Corn silage & 500 & 500 & 500 \\
Soybean meal & 102 & 102 & 102 \\
Barley hay & 105 & 105 & 105 \\
Corn grain & 250 & 250 & 250 \\
Calcium soaps of palm oil & 0 & 0 & 27 \\
Calcium soaps of canola oil & 0 & 27 & 0 \\
Calcium soaps of safflower oil & 27 & 0 & 0 \\
Vitamin and minerals premix ${ }^{1}$ & 16 & 16 & 16 \\
Chemical composition, g/kg DM & \\
Dry matter & 644 & 644 & 644 \\
Crude protein & 111 & 111 & 111 \\
Neutral detergent fiber & 395 & 395 & 395 \\
Acid detergent fiber & 203 & 203 & 203 \\
Ether extract & 40.6 & 40.7 & 40.9 \\
Ca & 2.1 & 2.2 & 2.2 \\
P & 2.9 & 2.9 & 2.9 \\
Petabolizable energy, MJ/kg DM ${ }^{2}$ & 12.0 & 12.0 & 12.0 \\
\hline
\end{tabular}

${ }^{1}$ Containing in $1.0 \mathrm{~kg}$ DM the following: $25 \mathrm{mg}$ of antioxidant, $4.5 \mathrm{~g}$ of calcium carbonate, $6 \mathrm{~g}$ of salt, $30 \mathrm{~g}$ of ionophore, $50 \mathrm{~g}$ of zinc oxide, $6 \mathrm{~g}$ of sodium bicarbonate, $6 \mathrm{~g}$ of copper sulphate, $20 \mathrm{~g}$ of ferrous sulphate, $125 \mathrm{~g}$ of sodium sulphate, $18,000 \mathrm{IU}$ of vitamin $\mathrm{E}, 3,000,000 \mathrm{UI}$ of vitamin $\mathrm{A}, 3,750,000 \mathrm{IU}$ of vitamin $\mathrm{D}, 140 \mathrm{~g}$ of potassium chloride, $0.500 \mathrm{~g}$ of EDD. I ethylene-dynamine, $0.090 \mathrm{~g}$ of cobalt carbonate, $500 \mathrm{mg}$ of magnesium oxide, $36 \mathrm{~g}$ of manganese oxide and $0.090 \mathrm{~g}$ of selenium. ${ }^{2}$ Calculated from NRC [19].

\subsection{Calcium Soap Elaboration}

Oils used for calcium soap elaboration had specific FA contents: palm oil was composed of $65 \mathrm{~g} / 100 \mathrm{~g}$ of palmitic acid, canola oil was composed of $65 \mathrm{~g} / 100 \mathrm{~g}$ of oleic acid and safflower oil was composed of $65 \mathrm{~g} / 100 \mathrm{~g}$ of linoleic acid.

The saponification process for canola and safflower oils was performed using the Jenkins and Palmquist [22] double decomposition method. Briefly, for each $100 \mathrm{~g}$ of oil, $25 \mathrm{~g}$ of calcium chloride, $5 \mathrm{~g}$ of calcium carbonate, $30 \mathrm{~mL}$ of $96 \%$ alcohol, $30 \mathrm{~mL}$ of $30 \%$ sodium hydroxide and distilled water were used. At the end of the saponification process, the soaps were introduced at $60^{\circ} \mathrm{C}$ for $48 \mathrm{~h}$ of dehydration [23]. The soaps were then ground to $1 \mathrm{~mm}$ in diameter and used in the experimental diets.

\subsection{Chemical Composition of Diets and Milk}

To determine the dry matter (DM) content in feed, refusals and feces, samples were dried in a forced-air oven at $60^{\circ} \mathrm{C}$ for $48 \mathrm{~h}$, and subsequently ground in a Wiley mill using a $3 \mathrm{~mm}$ screen (Arthur H. Thomas, Philadelphia). For experimental diets, organic matter (OM) was determined by incineration at $550{ }^{\circ} \mathrm{C}$ for $3 \mathrm{~h}$. Standard procedures [24] were used to determine the DM (934.01), Kjeldahl N (984.13), and ether extract (920.39). Neutral detergent fiber (NDF) and acid detergent fiber (ADF) were analyzed according to Van Soest et al. [21], including $\alpha$-amylase and sodium-sulfite for NDF analysis using the ANKOM system (ANKOM Technology, Macedon, NY,) for NDF and ADF.

Milk yield was recorded on the last 5 days of each experimental period, and was collected at $08.00 \mathrm{~h}$ using a volumetric milk meter and considered for statistical analysis. Samples were preserved with potassium dichromate and analyzed for protein, fat, lactose, total solids (TS) and non-fat solids (NFS) using a MilkoScan 133B (Foss Electric, Hillerød, Denmark).

\subsection{In Vitro Gas Production}

The in vitro gas production technique using a pressure transducer [25] was used to determine the kinetics of rumen fermentation. Three rumen cannulated lactating goats ( $40 \pm 3 \mathrm{~kg}$ of body weight) 
were used as donors of rumen fluid and fed with the same experimental basal diet. Equal amounts $(150 \mathrm{~mL})$ of rumen fluid were collected and filtered through four layers of cheesecloth.

The buffer solution was prepared according to Menke and Steingass [26], where $0.800 \mathrm{~g}$ DM of each ingredient and each diet mixture were incubated in glass bottles of $125 \mathrm{~mL}$. The bottles were filled under anaerobic conditions with $10 \mathrm{~mL}$ of rumen inoculum and $90 \mathrm{~mL}$ of an incubation solution in $1 \mathrm{~L}$. This solution consisted of $238 \mathrm{~mL} / \mathrm{L}$ of buffer solution $\left(14 \mathrm{~g} \mathrm{NaHCO}_{3}\right.$ and $1.5 \mathrm{~g}\left(\mathrm{NH}_{4}\right) \mathrm{HCO}_{3}$ per $\mathrm{L}), 238 \mathrm{~mL} / \mathrm{L}$ of a macro mineral solution $\left(5.7 \mathrm{~g} \mathrm{Na}_{2} \mathrm{HPO}_{4}, 6.2 \mathrm{~g} \mathrm{KH}_{2} \mathrm{PO}_{4}\right.$ and $0.6 \mathrm{~g} \mathrm{MgSO}_{4} .7 \mathrm{H}_{2} \mathrm{O}$ per L), $474 \mathrm{~mL} / \mathrm{L}$ of distilled water, $0.1 \mathrm{~mL} / \mathrm{L}$ of micro minerals $\left(13.2 \mathrm{~g} \mathrm{CuCl}_{22} \mathrm{H}_{2} \mathrm{O}, 10.0 \mathrm{~g} \mathrm{MnCl}_{24} \mathrm{H}_{2} \mathrm{O}\right.$, $1.0 \mathrm{~g} \mathrm{CoCl}_{26} \mathrm{H}_{2} \mathrm{O}, 8.0 \mathrm{~g} \mathrm{FeCl}_{26} \mathrm{H}_{2} \mathrm{O}$ and made up to $100 \mathrm{~mL}$ with $\mathrm{H}_{2} \mathrm{O}$ ) and $50 \mathrm{~mL} / \mathrm{L}$ of a reduction solution (47.5 mL distilled water, $2 \mathrm{~mL}$ of $1 \mathrm{~N} \mathrm{NaOH}$ and $313 \mathrm{mg} \mathrm{HCl}$-cysteine), and resazurin (phenoxazine dye). Two additional bottles without substrate were also prepared as blanks in order to adjust for the potential contribution of other soluble extracts on overall gas production and to correct readings of substrate, including bottles from the self-fermentation of rumen inocula.

Bottles were filled with the incubation solution under a $\mathrm{CO}_{2}$ stream, sealed and incubated for $96 \mathrm{~h}$ in a water bath at $39^{\circ} \mathrm{C}$. The gas volume was recorded at $3,6,9,12,24,36,48,72$ and $96 \mathrm{~h}$ of incubation in three series of incubation. The pressure produced on each bottle was measured with an HD8804 manometer provided with a TP804 pressure gauge (Delta OHM, Caselle di Selvazzano, Italy). Readings corrected for atmospheric pressure were converted to volume $(\mathrm{mL})$ using a pre-established linear regression $\left[\mathrm{mL}\right.$ gas $=(2.7384 \mathrm{x})-0.0243, \mathrm{n}=45, \mathrm{R}^{2}=0.994$, where $\mathrm{x}=\mathrm{psi} /$ hour $]$ and expressed as a unit of incubated DM.

The kinetic parameters for gas production (GP) were estimated through an iterative procedure of non-linear regression analysis (PROC NLIN) with SAS [27] according to Krishnamoorthy et al. [28] (1991) and calculated as:

$$
\mathrm{GP}=\mathrm{B}\left(1-\mathrm{e}^{-\mathrm{Ct}}\right)
$$

where GP = gas production $\left(\mathrm{mL}\right.$ gas $/ \mathrm{g}^{-1}$ initial $\left.\mathrm{DM}\right), \mathrm{B}=$ total gas production $\left(\mathrm{mL}\right.$ gas $\mathrm{g}^{-1}$ initial $\left.\mathrm{DM}\right)$, $\mathrm{C}=$ rate of degradation with respect to time (hours) and $t=$ time (h).

\subsection{Calculations}

Nutrient digestibility $(\mathrm{g} / \mathrm{kg})$ was determined as [(nutrient intake, $\mathrm{g} / \mathrm{d}$ - nutrient excreted, $\mathrm{g} / \mathrm{d}) /($ nutrient intake, $\mathrm{g} / \mathrm{d})] \times 1000$. Fat-corrected milk at $3.5 \%(\mathrm{FCM})$ was calculated as $\mathrm{FCM}(\mathrm{kg} / \mathrm{d})=$ [milk $(\mathrm{kg} / \mathrm{d}) \times 0.432]+[\mathrm{fat} \mathrm{kg} / \mathrm{d}) \times 16.216]$. Energy corrected milk $(\mathrm{ECM})$ was calculated as $\mathrm{ECM}=[\mathrm{milk}$ $(\mathrm{kg} / \mathrm{d}) \times 0.327]+[$ fat $(\mathrm{kg} / \mathrm{d}) \times 12.86]+[$ protein $(\mathrm{kg} / \mathrm{d}) \times 7.65]$ [29]. Feed efficiency $(\mathrm{FE})$ was calculated as FE $=$ milk yield $(\mathrm{kg} / \mathrm{d}) /$ dry matter intake $(\mathrm{kg} / \mathrm{d})$. Adjusted FE was $=3.5 \% \mathrm{FCM}(\mathrm{kg}) / \mathrm{DM}$ intake $(\mathrm{kg} / \mathrm{d})$ and milk production efficiency (MPE) was $=\mathrm{kg}$ of milk produced $/ \mathrm{kg}$ of crude protein ingested.

After $96 \mathrm{~h}$ of incubation, the accumulated gas was released, and the fermentation residues from each flask were dried at $60^{\circ} \mathrm{C}$ for $48 \mathrm{~h}$ to calculate the dry matter disappearance: DMD $(\mathrm{mg} / 100 \mathrm{mg})=$ $(\mathrm{DM}$ disappeared $96 \mathrm{~h}) /(\mathrm{DM}$ initial $) \times 100$, where: $\mathrm{DMD}(\mathrm{mg} / \mathrm{g} \mathrm{DM}$ disappeared at $96 \mathrm{~h}), \mathrm{DM}$ initial $(\mathrm{mg} / \mathrm{g} \mathrm{DM})$. The partitioning factor at $96 \mathrm{~h}$ of incubation (PF96-a measure of fermentation efficiency) was calculated as the ratio of in vitro DMD (DMD, $\mathrm{mg} / 100 \mathrm{mg}$ ) to the volume $(\mathrm{mL})$ of $\mathrm{GP}$ at $96 \mathrm{~h}$ (i.e., DMD/total gas production (GP96)) according to Blümmel et al. [30]. Gas yield (GY24) was calculated as the volume of gas ( $\mathrm{mL}$ gas/g DM) produced after $24 \mathrm{~h}$ of incubation divided by the amount of DMD (g) as: gas yield $(\mathrm{GY} 24)=(\mathrm{mL}$ gas $24 \mathrm{~h} / \mathrm{g} \mathrm{DM}) / \mathrm{g}$ DMD. Short-chain fatty acid (SCFA) concentrations were calculated according to Getachew et al. [31] (2002) as: SCFA (mmol/200 mg DM) $=0.0222 \mathrm{GP}-0.00425$. Where GP was the $24 \mathrm{~h}$ net gas production $(\mathrm{mL} / 200 \mathrm{mg} \mathrm{DM})$. Microbial crude protein (MCP) biomass production was calculated according to Blümmel et al. [30] as: $\mathrm{MCP}(\mathrm{mg} / \mathrm{g} \mathrm{DM})=\mathrm{mg} \mathrm{DMD}-(\mathrm{mL}$ gas $\times 2.2 \mathrm{mg} / \mathrm{mL}$ ), where $2.2 \mathrm{mg} / \mathrm{mL}$ was a stoichiometric factor that expressed $\mathrm{mg}$ of $\mathrm{C}, \mathrm{H}$ and $\mathrm{O}$ required for the production of SCFA gas associated with the production of $1 \mathrm{~mL}$ of gas. 


\subsection{Statistical Analysis}

The in vivo data was subjected to analysis of variance using the general linear model (GLM) procedure of SAS [27] in a replicated $(n=3) 3 \times 3$ Latin square design.

$$
\mathrm{Y}_{\mathrm{ijk}}=\mu+\mathrm{P}_{\mathrm{i}}+\mathrm{A}_{\mathrm{j}}+\mathrm{T}_{(\mathrm{k})}+\mathrm{E}_{\mathrm{ijk}}
$$

where $Y_{i j k}=$ response variable in period $i$, animal $j$, treatment $k$, and $\mu=$ overall mean, $P_{i}=$ effect of period $\mathrm{i}, \mathrm{A}_{\mathrm{j}}=$ effect of the animal, $\mathrm{T}_{(\mathrm{k})}=$ effect of treatment and $\mathrm{E}_{\mathrm{ijk}}=$ random error. The fixed effects were the experimental period and treatment, and the random effect was the individual goat. Least square means with their standard errors were reported, and treatment effects were declared significant at $p<0.05$. The in vitro gas production data were subjected to analysis of variance (ANOVA) using the general linear model (PROC GLM) from SAS [27]. The Tukey test $(p<0.05)$ was used to interpret any significant difference between the mean values. Mean differences were considered significant at $p<0.05$ and $p<0.001$. Standard errors of means were calculated from the residual mean square in the analysis of variance.

\section{Results and Discussion}

Supplementing different types of dietary fat can be a useful strategy to increase the energy supply for lactating animals without resorting to cereals, which can result in costly diets. Therefore, in the present study, the choice was to use a modest amount of dietary fat supplementation (as rumen-protected fats), which was enough to supply adequate amounts of dietary energy without compromising productive traits in lactating goats.

\subsection{Ingredients and Chemical Composition of Dietary Treatments}

Contents of DM, crude protein (CP), NDF and ADF in barley hay, corn silage and corn grain agreed with previous reports [19]. Except for ether extract (EE), dietary treatments did not change in their chemical composition because all treatments had the same basal diet, which was formulated to be iso-proteic and iso-energetic.

\subsection{Nutrient Intake and Digestibility}

Metabolic live weight was similar among treatments (Table 3). Data related to the effects of lipid supplementation on body weight changes in lactating goats are limited, and responses are usually variable between protected and unprotected vegetable oil sources [32]. In this study, the observed changes were relatively small, showing that animals were, on average, under a positive energy balance, and this was observed with body-weight gains at the end of the experimental trial. 
Table 3. Nutrient intake and digestibility of goats supplemented with safflower oil (SO), canola oil (CO) and palm oil (PO) treatments ${ }^{1}$.

\begin{tabular}{|c|c|c|c|c|c|}
\hline Item & SO & $\mathrm{CO}$ & PO & SEM & $p$-Value \\
\hline Initial live weight, $\mathrm{LW}, \mathrm{kg}$ & 52.0 & 51.1 & 51.6 & 1.64 & 0.938 \\
\hline Final live weight, LW, $\mathrm{kg}$ & 52.6 & 51.3 & 54.6 & 1.76 & 0.453 \\
\hline Average live weight, $\mathrm{LW}, \mathrm{kg}$ & 52.3 & 51.2 & 53.1 & 1.37 & 0.635 \\
\hline Average metabolic live weight, $\mathrm{LW}^{0.75}$ & 19.4 & 19.1 & 19.6 & 0.38 & 0.637 \\
\hline \multicolumn{6}{|c|}{ Intake, $\mathrm{g} / \mathrm{d}$} \\
\hline Dry matter & 1820 & 1968 & 2020 & 175 & 0.716 \\
\hline Organic matter & 1667 & 1765 & 1810 & 157 & 0.812 \\
\hline Neutral detergent fiber & 720 & 779 & 800 & 69.1 & 0.716 \\
\hline Acid detergent fiber & 370 & 400 & 411 & 35.5 & 0.717 \\
\hline Fat & 74 & 80 & 82 & 7.11 & 0.689 \\
\hline Metabolizable energy, MJ/d ${ }^{2}$ & 20 & 21 & 22 & 1.90 & 0.803 \\
\hline \multicolumn{6}{|c|}{ Intake, $\mathrm{g} / \mathrm{kg} \mathrm{LW}^{0.75}$} \\
\hline Dry matter & 92.9 & 102 & 105 & 10.2 & 0.709 \\
\hline Organic matter & 85.1 & 91.7 & 93.7 & 9.21 & 0.795 \\
\hline Neutral detergent fiber & 36.8 & 40.5 & 93.4 & 4.05 & 0.709 \\
\hline Acid detergent fiber & 18.9 & 20.8 & 21.3 & 2.08 & 0.709 \\
\hline Fat & 3.8 & 4.2 & 4.3 & 0.42 & 0.686 \\
\hline Metabolizable energy, MJ/d 2 & 1.02 & 1.10 & 1.13 & 0.11 & 0.795 \\
\hline \multicolumn{6}{|c|}{ Digestibility, $\mathrm{g} / \mathrm{kg}$} \\
\hline Dry matter & $552^{\mathrm{b}}$ & $653^{a}$ & $588^{b}$ & 15.5 & 0.001 \\
\hline Organic matter & $559^{b}$ & $663^{a}$ & $606^{\mathrm{ab}}$ & 17.6 & 0.001 \\
\hline Neutral detergent fiber & $460^{b}$ & $616^{\mathrm{a}}$ & $510^{b}$ & 17.5 & 0.001 \\
\hline Acid detergent fiber & $424^{\mathrm{c}}$ & $658^{a}$ & $519^{b}$ & 16.9 & 0.001 \\
\hline
\end{tabular}

${ }^{\mathrm{a}-\mathrm{c}}$ Different literals within the same column show significant differences $(p<0.05)$. SEM $=$ standard error mean.

1 Treatments were calcium soaps of safflower oil (SO), canola oil (CO) and palm oil (PO, Megalac- $\mathrm{R}^{\circledR}$, Arm \& Hammer Animal Nutrition, Princenton, NJ, USA), supplemented at $2.7 \% \mathrm{DM} ;{ }^{2}$ Calculated from NRC [14].

Appropriate nutrient intake and digestibility are key factors influencing productive traits in lactating animals. These factors determine the profitability of animal production systems. Nutrient intakes were similar between treatments, which agreed with Bernard et al. [33], who fed goats with sunflower and linseed and found similar DM intakes. It is important to note that dietary treatments were formulated to be iso-proteic and iso-energetic and, therefore, no differences were expected with regard to nutrient intake.

Calcium soaps of $\mathrm{CO}$ were more digestible compared with $\mathrm{SO}$ and PO (Table 3). Several studies have mentioned that the use of calcium soaps does not have any adverse effect on dry matter digestibility $[34,35]$. Although dietary treatments in this study had similar chemical composition, it may be possible that the fiber contents (NDF and ADF) from SO and PO affected fibrolytic bacteria. However, this contention warrants further investigation. In this study, canola oil had around $65 \%$ oleic acid, which is a monounsaturated FA and is therefore less toxic to some of the ruminal microorganisms, which may be the reason for the higher digestibility shown in the CO treatment $[36,37]$.

\subsection{Nitrogen Balance}

No differences were observed for $\mathrm{N}$ intake and excretion (Table 4). The lack of differences in $\mathrm{N}$ utilization attests to the uniformity of energy and crude protein contents of dietary treatments. Dietary energy is one of the most important factors to consider in ruminant diets as it has a direct impact on microorganisms and overall protein metabolism at the rumen level [38]. Therefore, if dietary treatments were iso-energetic, no changes to $\mathrm{N}$ utilization were expected. The animals fed with $\mathrm{CO}$ and $\mathrm{PO}$ treatments were found in positive nitrogen balance, and only with $\mathrm{SO}$ treatment were we able to observe a numerical $\mathrm{N}$ loss of $0.03 \mathrm{~g} / \mathrm{kg}$ LW. In ruminants, it has been reported that dietary FA affects microbial protein synthesis, protozoa counts and methanogen profile [39], which can contribute to improving the efficiency of energy utilization of the feeding [4]. However, no differences in $\mathrm{N}$ balance 
were found between treatments in this study. The positive $\mathrm{N}$ balance found with $\mathrm{CO}$ and PO diets indicated the capacity of the diets to supply the $\mathrm{N}$ required for the goat's maintenance, without the need for energy mobilization from body reserves, and while also supplying adequate amounts of protein to rumen microorganisms [19].

Table 4. Nitrogen balance $\left(\mathrm{g} / \mathrm{d}, \mathrm{g} / \mathrm{kg} \mathrm{LW}^{0.75}\right)$ in dairy goats fed with safflower oil (SO), canola oil (CO) and palm oil (PO) treatments ${ }^{1}$.

\begin{tabular}{|c|c|c|c|c|c|}
\hline Item & SO & $\mathrm{CO}$ & PO & SEM & $p$-Value \\
\hline \multicolumn{6}{|c|}{$\mathrm{g} / \mathrm{d}$} \\
\hline $\mathrm{N}$ intake & 32.46 & 35.09 & 36.04 & 3.11 & 0.716 \\
\hline \multicolumn{6}{|l|}{$\mathrm{N}$ excretion } \\
\hline Urine & 11.79 & 12.87 & 13.84 & 2.61 & 0.860 \\
\hline Feces & 21.18 & 12.52 & 16.40 & 3.30 & 0.257 \\
\hline N Balance & -0.51 & 9.69 & 5.79 & 4.41 & 0.326 \\
\hline \multicolumn{6}{|c|}{$\mathrm{g} / \mathrm{kg} \mathrm{LW}{ }^{0.75}$} \\
\hline $\mathrm{N}$ intake & 1.65 & 1.82 & 1.86 & 0.18 & 0.709 \\
\hline \multicolumn{6}{|l|}{ N excretion } \\
\hline Urine & 0.60 & 0.66 & 0.71 & 0.13 & 0.852 \\
\hline Feces & 1.08 & 0.64 & 0.85 & 0.17 & 0.294 \\
\hline N Balance & -0.03 & 0.51 & 0.30 & 0.23 & 0.323 \\
\hline
\end{tabular}

${ }^{1}$ Treatments were calcium soaps of safflower oil (SO), canola oil (CO) and palm oil (PO, Megalac- ${ }^{\circledR}$, Arm \& Hammer Animal Nutrition, Princenton, NJ, USA), supplemented at $2.7 \%$ DM.

\subsection{Milk Production and Milk Composition}

Milk production (Table 5) was higher in SO compared with CO and PO. Mir et al. [40] fed dairy goats with four inclusion levels of canola oil without observing any effect on milk production. Similarly, Chilliard et al. [41] and Lock et al. [42] reported that the supplementation of fats in dairy goat diets had no effect on milk production. In contrast, Lu [43] found a decrease in milk production with the supplementation of animal fat at 5\% DM in lactating goats. In order to have more accurate inferences for milk production, milk production efficiency, corrected by fat (fat-corrected milk 3.5\%), energy (energy-corrected milk) and feed efficiency (feed efficiency and fat-corrected milk 3.5\%), were calculated, and similar results were obtained between treatments. This was a unique feature of the study, as the calculations allowed us to understand milk production from different angles. Thus, it appeared that SO was the best for milk yield, but if we accounted for energy utilization from the diet, all treatments resulted in similar values.

Palmquist [44] reported that fat supplementation increases energetic efficiency in lactating cows by increasing total energy intake by generating ATP more efficiently compared with volatile fatty acids, and by directly incorporating long-chain FA into milk fat. Also, one mechanism proposed for the increase in milk yield with fat supplementation is glucose sparing, in which the suppression of de novo FA synthesis in the mammary gland decreases the oxidative use of glucose to generate reducing equivalents for milk fat synthesis [45]. This extra glucose may be utilized in other milk processes, including lactose synthesis and increased milk yield [46].

Contrary to cow research, some articles have mentioned that the use of fat supplements does not change milk production in dairy goats $[32,41]$. With regard to fat and protein content in milk, CO was lower than SF and PO. Although dietary lipid supplementation in dairy goats generally improves milk fat production [32], in this study, this was not the case for CO treatment, which resulted in the lowest amount of fat. It has been reported that the effect of supplemental fats on milk fat is not always positive since it is influenced by their percentage of inclusion in the diet, type of forages in the diet, type of supplemental fat (rumen-protected or not), physical form (i.e., whole seeds and oils) and the chemical composition of dietary lipids (saturated or unsaturated fatty acids) [41].

It is worth mentioning that $\mathrm{CO}$ resulted in inferior ruminal fermentation performance, as shown by a reduction in total gas production (Figure 1) and a reduction in the amount of SCFA, which could 
have influenced the lower amount of milk fat found for this treatment. This is important since SCFAs, such as acetate and butyric acids, play an important role in the formation of short-chain fatty acids (C4:0 to C14:0) in milk. These fatty acids account for approximately 60 and $45 \%$ of the total milk fatty acids on a molar and weight basis, respectively [47].

Non-fat solids were lower in $\mathrm{CO}$ and $\mathrm{PO}$ compared with $\mathrm{SO}$, and total solids were higher for SO compared with PO and $\mathrm{CO}$. The addition of fat leads to a reduction in rumen fermentable organic matter, reduction in precursors of glucose and reduction in the synthesis of microbial protein, and thus a reduction in the amount of amino acids available for the synthesis protein in milk. This explains why a lower amount of protein in milk was observed with regard to the fat content.

Some studies have reported a reduction of protein in milk in which long-chain FAs were abomasally infused in cows, and showed that the magnitude of changes in milk components depended on the amount and type of FA supplied [48]. Despite the fact that dietary treatments supplied similar protein and energy, the type of FA in each calcium soap elicited differential effects on protein contents in milk, and in this case, $\mathrm{CO}$ resulted in a detrimental effect on this milk component.

For lactose content in milk, no differences were observed among treatments $(p>0.05)$; however, Luna et al. [49] reported differences in goat milk lactose when the diets were supplemented with whole linseed (1.84\% DM) and sunflower oil (0.81\% DM). Ayeb et al. [50] found no differences in the lactose content of goat milk when animals were fed dry olive leaves ad libitum. These authors reported an increase of the total solids when dry olive leaves were included in the diet.

Table 5. Milk yield (kg/d) and milk composition from dairy goats supplemented with safflower oil (SO), canola oil (CO) and palm oil (PO) treatments ${ }^{1}$.

\begin{tabular}{cccccc}
\hline Item & SO & CO & PO & SEM & $p$-Value \\
\hline Milk production, kg/d & $1.10^{\mathrm{a}}$ & $0.95^{\mathrm{b}}$ & $0.88^{\mathrm{b}}$ & 0.09 & 0.009 \\
Fat-corrected milk 3.5\% & 1.07 & 0.93 & 0.88 & 0.18 & 0.740 \\
Energy corrected milk & 1.08 & 0.99 & 0.86 & 0.17 & 0.667 \\
Feed efficiency & 0.36 & 0.30 & 0.24 & 0.05 & 0.169 \\
FE FCM & 0.36 & 0.30 & 0.25 & 0.05 & 0.265 \\
Milk production efficiency & 6.19 & 6.59 & 4.80 & 0.88 & 0.330 \\
Fat, g/d & $35.0^{\mathrm{a}}$ & $32.3^{\mathrm{b}}$ & $34.3^{\mathrm{a}}$ & 0.56 & 0.002 \\
Protein, g/d & $37.7^{\mathrm{a}}$ & $29.8^{\mathrm{b}}$ & $34.6^{\mathrm{a}}$ & 0.48 & 0.003 \\
Lactose, g/d & 45.1 & 39.9 & 37.0 & 3.82 & 0.076 \\
Total solids, g/d & $127^{\mathrm{a}}$ & $111^{\mathrm{b}}$ & $113^{\mathrm{b}}$ & 0.85 & 0.005 \\
Non-fat solids, g/d & $100^{\mathrm{a}}$ & $78.9^{\mathrm{b}}$ & $78.9^{\mathrm{b}}$ & 0.96 & 0.002 \\
Fat, g/kg & $33^{\mathrm{b}}$ & $35^{\mathrm{b}}$ & $41^{\mathrm{a}}$ & 0.52 & 0.001 \\
Protein, g/kg & $35^{\mathrm{b}}$ & $33^{\mathrm{b}}$ & $41^{\mathrm{a}}$ & 0.57 & 0.003 \\
Lactose, g/kg & $41^{\mathrm{k}}$ & $4^{\mathrm{b}}$ & $4^{\mathrm{b}}$ & 0.85 & 0.365 \\
Total solids, g/kg & $120^{\mathrm{b}}$ & $122^{\mathrm{b}}$ & $136^{\mathrm{a}}$ & 1.75 & 0.049 \\
Non-fat solids, g/kg & $95^{\mathrm{a}}$ & $86^{\mathrm{b}}$ & $94^{\mathrm{a}}$ & 0.91 & 0.002 \\
\hline
\end{tabular}

a,b Different literals within the same column show significant differences $(p<0.05)$. SEM $=$ standard error

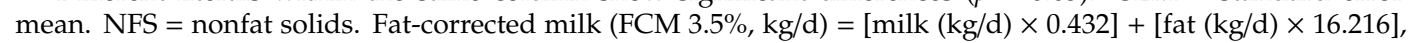
energy corrected milk $(\mathrm{ECM})=[\operatorname{milk}(\mathrm{kg} / \mathrm{d}) \times 0.327]+[\mathrm{fat}(\mathrm{kg} / \mathrm{d}) \times 12.86]+[$ protein $(\mathrm{kg} / \mathrm{d}) \times 7.65][24]$, feed efficiency $(\mathrm{FE})=$ milk yield $(\mathrm{kg} / \mathrm{d}) / \mathrm{dry}$ matter intake $(\mathrm{kg} / \mathrm{d})$, feed efficiency corrected $(\mathrm{FE} \mathrm{FCM})=$ milk yield $(\mathrm{FCM}, 3.5 \%$, $\mathrm{kg} / \mathrm{d}) / \mathrm{dry}$ matter intake $(\mathrm{kg} / \mathrm{d}), \mathrm{MPE}=$ milk production efficiency $(\mathrm{kg}$ of milk produced $/ \mathrm{kg}$ of crude protein ingested). ${ }^{1}$ Treatments were calcium soaps of safflower oil (SO), canola oil (CO) and palm oil (PO, Megalac- ${ }^{\circledR}$, Arm \& Hammer Animal Nutrition, Princenton, NJ, USA), supplemented at 2.7\% DM. 


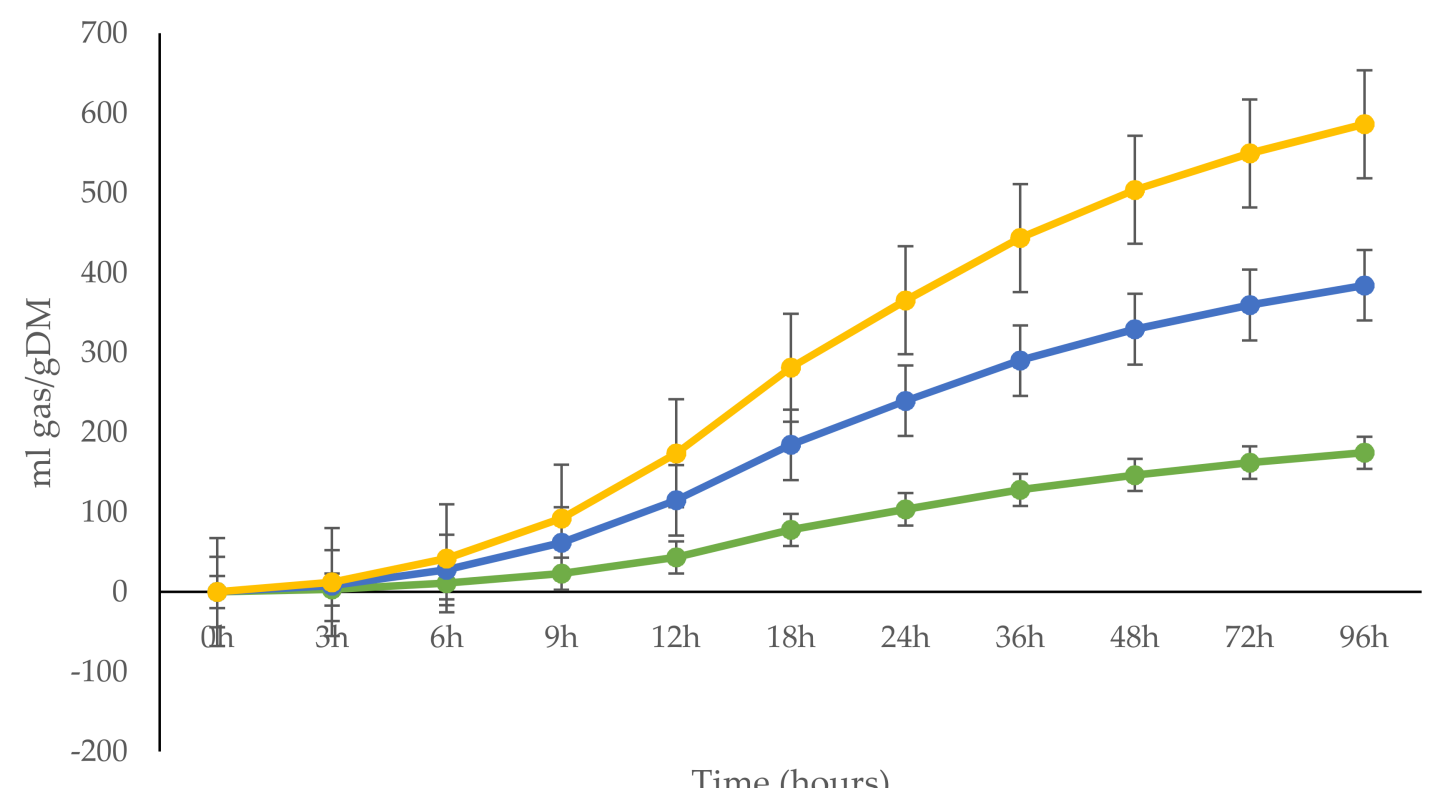

Time (hours)

Figure 1. Total gas production (mL gas/g DM) over $96 \mathrm{~h}$ of in vitro incubation from calcium soaps of palm oil (yellow line), safflower oil (blue line) and canola oil (green line).

\subsection{In Vitro Gas Production}

The parameters of the in vitro gas production of the ingredients used in the diets are presented in Table S1. Differences in gas production for each ingredient $(p<0.001)$ were observed, being higher $(p<0.001)$ in corn silage and corn grain, and lower in PO. The fractional rate of degradation (c) and lag time was similar among ingredients $(p>0.1)$, DMD $96 \mathrm{~h}$ was higher $(p<0.001)$ for soybean and corn grain, followed by barley hay and corn silage, with DMD being lower for safflower oil, canola oil and palm oil. PG $96 \mathrm{~h}$ was higher $(p<0.05)$ for corn grain than for the other ingredients. Gas production is an indirect measure of the degradation of substrates, particularly from carbohydrates. Furthermore, it is an estimator for the production of short-chain fatty acids [30,51]. GY $24 \mathrm{~h}$, SCFA and MCP synthesis was higher $(p<0.001)$ for soybean, corn grain and barley hay compared to SO, CO and PO (Figure S1). The results obtained mirrored the chemical composition of each feedstuff, which could increase or decrease microbial fermentation in addition to the fact that $\mathrm{SO}, \mathrm{PO}$ and $\mathrm{CO}$ are protected fats, and protected fats in the form of calcium soaps usually depress gas production [31].

The in vitro gas production parameters were different between treatments $(p<0.002)$ (Table 6). Increased gas production (mL gas/g DM) and the " $\mathrm{c}$ " fraction were higher for $\mathrm{SO}(p<0.001)$ followed by $\mathrm{PO}$, where the inclusion of $\mathrm{CO}$ affected the gas production and fermentation rate. Lag time was higher $(p<0.001)$ for $\mathrm{CO}$ than SO. Fat, oils and grease have negative effects on rumen fermentation, which are associated with the inhibition of microbial activity, particularly microorganism methanogenic activity [52]. It has been mentioned for many years that oil supplementation, particularly with unsaturated oils, affects and modifies the microbial activity of the rumen, which is involved in cellulose degradation. Also, it has been explained that these factors are due to the fact that fats coat the ruminal bacteria, disrupting cell membrane functions, and that long-chain fatty acids are toxic to cellulolytic bacteria [53].

In the present study, less gas production was observed in the treatment of $\mathrm{CO}$, followed by $\mathrm{SO}$, which are unsaturated fatty acids such as linoleic acid. As mentioned above, this type of fatty acid is toxic, causing fewer protozoa and bacteria in the rumen, which explains our findings. The DMD $96 \mathrm{~h}, \mathrm{PF} 96 \mathrm{~h}$ and MCP were not affected among treatments $(p>0.1)$. GY $24 \mathrm{~h}$ and SCFA were higher $(p<0.001)$ for SO and PO than CO. Under the conditions of this study, results from in vitro gas production pointed at the fact that there were differential effects on rumen fermentation based on the degree of FA saturation as palm oil was a saturated FA source, $\mathrm{CO}$ was mainly a monounsaturated 
FA and SO was primarily formed by polyunsaturated FA. In this study, treatments exerted different magnitudes of change that, to some degree, led to the inhibition of ruminal fermentation processes and affected carbohydrate digestion [54]. Overall, the discrepancies between the higher digestibility detected with $\mathrm{CO}$ and its lower gas production remain unknown, and perhaps analyzing the rumen microbiome will clarify these findings.

Table 6. in vitro rumen gas kinetics, cumulative gas production and rumen fermentation profile, after $96 \mathrm{~h}$ of incubation in goat diets supplemented with safflower oil (SO), canola oil (CO) and palm oil (PO) treatments ${ }^{1}$.

\begin{tabular}{|c|c|c|c|c|c|}
\hline Item & SO & $\mathrm{CO}$ & PO & SEM & $p$-Value \\
\hline B & $206^{d}$ & $174^{\mathrm{e}}$ & $201^{d}$ & 4.6 & $<0.001$ \\
\hline $\mathrm{C}$ & $0.05^{\mathrm{d}}$ & $0.04^{\mathrm{e}}$ & 0.04 de & 0.001 & 0.001 \\
\hline Lag time & $4.47^{\mathrm{e}}$ & $5.23^{\mathrm{d}}$ & $4.86^{\text {de }}$ & 0.188 & 0.030 \\
\hline \multicolumn{6}{|c|}{ Gas production, $\mathrm{mL}$ gas/g DM } \\
\hline $6 \mathrm{~h}$ & $16.6^{\mathrm{a}}$ & $11.0^{\mathrm{b}}$ & $14.3^{\mathrm{ab}}$ & 1.42 & 0.033 \\
\hline $12 \mathrm{~h}$ & $71.3^{a}$ & $43.5^{b}$ & $58.5^{\mathrm{a}}$ & 3.56 & $<0.001$ \\
\hline $24 \mathrm{~h}$ & $135^{a}$ & $103^{b}$ & $125^{\mathrm{a}}$ & 4.59 & $<0.001$ \\
\hline $48 \mathrm{~h}$ & $182^{\mathrm{a}}$ & $146^{\mathrm{b}}$ & $174^{\mathrm{a}}$ & 4.97 & $<0.001$ \\
\hline DMD $96 \mathrm{~h}$ & 74 & 72 & 77 & 5.6 & 0.782 \\
\hline PF $96 \mathrm{~h}$ & 290 & 293 & 263 & 34.8 & 0.796 \\
\hline GY $24 \mathrm{~h}$ & $33.9^{a}$ & $25.9^{b}$ & $31.4^{\mathrm{a}}$ & 1.14 & $<0.001$ \\
\hline SCFA & $0.75^{a}$ & $0.57^{\mathrm{b}}$ & $0.69^{a}$ & 0.03 & $<0.001$ \\
\hline MCP & 670 & 660 & 704 & 57.6 & 0.854 \\
\hline
\end{tabular}

a,b,d,e Mean values in the same row with different literals are statistically different. SEM $=$ standard error of the mean. ${ }^{1}$ Treatments were calcium soaps of safflower oil (SO), canola oil (CO) and palm oil (PO; Megalac-R ${ }^{\circledR}$ Arm \& Hammer Animal Nutrition, Princenton, NJ, USA). B = fermentation rate $\left(\mathrm{h}^{-1}\right), \mathrm{C}=$ fermentation rate $\left(\mathrm{h}^{-1 / 2}\right)$, lag time = time in which fermentation starts, DMD $96 \mathrm{~h}=$ dry matter disappeared at $96 \mathrm{~h}(\mathrm{mg} / 100 \mathrm{mg}) ; \mathrm{PF} 96=$ partition factor (mL gas/g DMD $96 \mathrm{~h})$; GY $24 \mathrm{~h}$ = gas production at $24 \mathrm{~h}(\mathrm{~mL}$ gas/g DM), SCFA = short-chain fatty acids $(\mathrm{mL} / 200 \mathrm{mg} \mathrm{DM}), \mathrm{MCP}=$ microbial protein $(\mathrm{mg} / \mathrm{g} \mathrm{DM})$.

Taken together, our study confirms pioneer studies (i.e., [17]) reporting that calcium soaps are an effective source of fat for dairy rations because ruminal fermentation is normal or at least not negatively affected, digestibility of fatty acids is high and soaps are mixed easily with other feed ingredients (as observed when diets and treatments are mixed and supplied).

\section{Conclusions}

Overall, compared with the traditional use of calcium soaps manufactured from $\mathrm{PO}$, at an inclusion of $2.7 \% \mathrm{DM}$, calcium soaps of $\mathrm{SO}$ can be used in goat diets to increase milk production, milk protein and milk fat yields without negative effects on nutrient intake and digestibility. Further studies should consider the analysis of milk fatty acid profiles to evaluate the transfer of dietary fatty acids supplied into milk fat and rumen microbiome analysis warrants further attention in order to improve our understanding on nutrient digestibility and in vitro gas production.

Supplementary Materials: The following are available online at https://zenodo.org/record/3928288\# .X2iWoWgzZaS, Figure S1: Total gas production (mL gas/g DM) from feedstuffs used for the experiment: corn grain cracked*; soybean meal, $\mathbf{O}$; barley hay, $\bullet$; canola oil, $\mathbf{\square}$; palm oil, $\mathbf{\Delta}$; safflower oil, $\mathbf{O}$; corn silage, $\mathbf{\Lambda}$. Table S1: in vitro rumen gas kinetics, cumulative gas production and rumen fermentation profile after $96 \mathrm{~h}$ of incubation as affected by the ingredients used in goats with different calcium soaps sources.

Author Contributions: Conceptualization, M.G.-R., O.A.C.-O., N.P.-S. and E.V.-B.-P.; methodology, M.G.-R. and J.R.-B.; software, M.G.-R., J.R.-B. and R.A.-H.; validation, M.G.-R., E.V.-B.-P. and L.E.R.-J.; formal analysis, J.R.-B. and L.E.R.-J.; investigation, R.A.-H., J.R.-B. and M.G.-R.; resources, M.G.-R., N.P.-S. and O.A.C.-O.; data curation, R.A.-H. and J.R.-B.; writing-original draft preparation, L.E.R.-J., M.G.-R. and E.V.-B.-P.; writing-review and editing, L.E.R.-J., M.G.-R. and E.V.-B.-P.; visualization, O.A.C.-O., N.P.-S. and M.G.-R.; supervision M.G.-R.; project administration, M.G.-R.; funding acquisition, M.G.-R., O.A.C.-O. and N.P.-S. All authors have read and agreed to the published version of the manuscript. 
Funding: This research was funded by Universidad Autónoma del Estado de México (Project ID UAEMex 3060-2011 and UAEMex4974/2020).

Acknowledgments: J Romero-Bernal and L.E. Robles-Jimenez were granted by CONACYT Fellowship and E Vargas-Bello-Perez was supported by a visiting scholarship by Universidad Autónoma del Estado de México.

Conflicts of Interest: The authors declare no conflict of interest.

\section{References}

1. Sanz Sampelayo, M.R.; Chilliard, Y.; Schmidely, P.; Boza, J. Influence of type of diet on the fat constituents of goat and sheep milk. Small Rumin. Res. 2007, 68, 42-63. [CrossRef]

2. Abubakr, A.; Alimon, A.R.; Yaakub, H.; Abdullah, N.; Ivan, M. Effect of feeding palm oil by-products based diets on muscle fatty acid composition in goats. PLoS ONE 2015, 10, e0119756. [CrossRef] [PubMed]

3. Karami, M.; Ponnampalam, E.N.; Hopkins, D.L. The effect of palm oil or canola oil on feedlot performance, plasma and tissue fatty acid profile and meat quality in goats. Meat Sci. 2013, 94, 165-169. [CrossRef] [PubMed]

4. Adeyemi, K.D.; Sazili, A.Q.; Ebrahimi, M.; Samsudin, A.A.; Alimon, A.R.; Karim, R.; Karsani, S.A.; Sabow, A.B. Effects of blend of canola oil and palm oil on nutrient intake and digestibility, growth performance, rumen fermentation and fatty acids in goats. Anim. Sci. J. 2016, 87, 1137-1147. [CrossRef] [PubMed]

5. Li, X.Z.; Yan, C.G.; Lee, H.G.; Choi, C.W.; Song, M.K. Influence of dietary plant oils on mammary lipogenic enzymes and the conjugated linoleic acid content of plasma and milk fat of lactating goats. Anim. Feed Sci. Technol. 2012, 174, 26-35. [CrossRef]

6. Jenkins, T.C.; Bridges, W.C., Jr. Protection of fatty acids against ruminal biohydrogenation in cattle. Eur. J. Lipid Sci. Technol. 2007, 109, 778-789. [CrossRef]

7. Silva, M.M.C.D.; Rodrigues, M.T.; Branco, R.H.; Rodrigues, C.A.F.; Sarmento, J.L.R.; Queiroz, A.C.D.; Silva, S.P.D. Suplementação de lipídios em dietas para cabras em lactação: Consumo e eficiência de utilização de nutrientes. Rev. Bras. Zootec. 2007, 36, 257-267. [CrossRef]

8. Sanz Sampelayo, M.R.; Pérez, L.; Martín Alonso, J.J.; Gil Extremera, F.; Boza, J. Effects of concentrates with different contents of protected fat rich in PUFAs on the performance of lactating Granadina goats: 1. Feed intake, nutrient digestibility, $\mathrm{N}$ and energy utilisation for milk production. Small Rumin. Res. 2002, 43, 133-139. [CrossRef]

9. Casals, R.; Caja, G.; Such, X.; Torre, C.; Calsamiglia, S. Effects of calcium soaps and rumen undegradable protein on the milk production and composition of dairy ewes. J. Dairy Res. 1999, 66, 177-191. [CrossRef]

10. Abdelhakim, H.H.; Abdelhafeez, H.M.; Tawfeek, S.S.; Hegazy, M.A. Effect of calcium soap of palm oil fatty acids on milk composition, ewe and lamb performance in a crossbred sheep. J. Vet. Med. Res. 2016, 23, 46-60. [CrossRef]

11. Manso, T.; Castro, T.; Mantecón, A.R.; Jimeno, V. Effects of palm oil and calcium soaps of palm oil fatty acids in fattening diets on digestibility, performance and chemical body composition of lambs. Anim. Feed Sci. Technol. 2006, 127, 175-186. [CrossRef]

12. Chouinard, P.Y.; Corneau, L.; Butler, W.R.; Bauman, D.E.; Chilliard, Y.; Drackley, J.K. Effect of Dietary Lipid Source on Conjugated Linoleic Acid Concentrations in Milk Fat1,2. J. Dairy Sci. 2001, 84, 680-690. [CrossRef]

13. Castro, T.; Manso, T.; Jimeno, V.; Del Alamo, M.; Mantecón, A.R. Effects of dietary sources of vegetable fats on performance of dairy ewes and conjugated linoleic acid (CLA) in milk. Small Rumin. Res. 2009, 84, 47-53. [CrossRef]

14. Savoini, G.; Omodei Zorini, F.; Farina, G.; Agazzi, A.; Cattaneo, D.; Invernizzi, G. Effects of Fat Supplementation in Dairy Goats on Lipid Metabolism and Health Status. Animals 2019, 9, 917. [CrossRef]

15. Vargas-Bello-Pérez, E.; Vera, R.R.; Aguilar, C.; Lira, R.; Peña, I.; Fernández, J. Feeding olive cake to ewes improves fatty acid profile of milk and cheese. Anim. Feed Sci. Technol. 2013, 184, 94-99. [CrossRef]

16. Vargas-Bello-Pérez, E.; Vera, R.R.; Aguilar, C.; Lira, R.; Peña, I.; Valenzuela, A.; Cerda, H. Effect of dietary inclusion of lampante olive oil on milk and cheese fatty acid profiles of ewes. Grasas Aceites 2013, 64, 295-303. [CrossRef]

17. Vargas-Bello-Pérez, E.; Zhao, W.; Bionaz, M.; Luo, J.; Loor, J.J. Nutrigenomic Effect of Saturated and Unsaturated Long Chain Fatty Acids on Lipid-Related Genes in Goat Mammary Epithelial Cells: What Is the Role of PPAR $\gamma$ ? Vet. Sci. 2019, 6, 54. [CrossRef] 
18. de Souza, J.; Batistel, F.; Santos, F.A.P. Effect of sources of calcium salts of fatty acids on production, nutrient digestibility, energy balance, and carryover effects of early lactation grazing dairy cows. J. Dairy Sci. 2017, 100, 1072-1085. [CrossRef]

19. NRC. Nutrient Requirements of Small Ruminants: Sheep, Goats, Cervids, and New World Camelids; National Academies Press: Washington, DC, USA, 2007; p. 362.

20. AOAC. Association of Official Analytical Chemists. In Official Methods of Analysis, 18th ed.; AOAC: Gaithersburg, MD, USA, 2005; p. 432.

21. Van Soest, P.J.; Robertson, J.B.; Lewis, B.A. Methods for Dietary Fiber, Neutral Detergent Fiber, and Nonstarch Polysaccharides in Relation to Animal Nutrition. J. Dairy Sci. 1991, 74, 3583-3597. [CrossRef]

22. Jenkins, T.C.; Palmquist, D.L. Effect of fatty acids or calcium soaps on rumen and total nutrient digestibility of dairy rations. J. Dairy Sci. 1984, 67, 978-986. [CrossRef]

23. Romero-Davila, A.; Herrera-Corredor, C.; Calderón-Aranda, J.A.; Buendía-Rodriguez, G.; Pescador Salas, N.; González-Ronquillo, M. Uso de jabones de calcio como alternativa de suplementación en rumiantes en épocas se sequia en zonas áridas y semiáridas. In SUSTENTABILIDAD AGROPECUARIA, Experiencias de Investigación Para el Desarrollo Agropecuario, Forestal y Rural; Brunett Perez, L., William, G.D., Gutierrez Castillo, A., Jaimes Arriaga, E., Eds.; Colofón: Ciudad de Mexico, Mexico; Universidad Autónoma del Estado de Mexico: Estado de Mexico, Mexico, 2017; pp. 155-168, ISBN 978607858301.

24. AOAC. Association of Official Analytical Chemists. In Official Methods of Analysis Review 3, 18th ed.; AOAC: Gaithersburg, MD, USA, 2010.

25. Theodorou, M.K.; Williams, B.A.; Dhanoa, M.S.; McAllan, A.B.; France, J. A simple gas production method using a pressure transducer to determine the fermentation kinetics of ruminant feeds. Anim. Feed Sci. Technol. 1994, 48, 185-197. [CrossRef]

26. Menke, K.H.; Steingass, H. Estimation of energetic feed value obtained from chemical analyses and in vitro gas production using rumen fluid. Anim. Res. Dev. 1988, 28, 7-55.

27. SAS. Statistical Analysis Systems Institute. User's Guide Version Eight; SAS Institute Inc.: Cary, NC, USA, 2002.

28. Krishnamoorthy, U.; Soller, H.; Steingass, H.; Menke, K.H. A comparative study on rumen fermentation of energy supplements in vitro. J. Anim. Physiol. Anim. Nutr. 1991, 65, 28-35. [CrossRef]

29. Tyrrell, H.F.; Reid, J.T. Prediction of the Energy Value of Cow's Milk1, 2. J. Dairy Sci. 1965, 48, 1215-1223. [CrossRef]

30. Blümmel, M.; Steingass, H.; Becker, K. The relationship between in vitro gas production, in vitro microbial biomass yield and $15 \mathrm{~N}$ incorporation and its implications for the prediction of voluntary feed intake of roughages. Br. J. Nutr. 1997, 77, 911-921. [CrossRef]

31. Getachew, G.; Makkar, H.P.S.; Becker, K. Tropical browses: Contents of phenolic compounds, in vitro gas production and stoichiometric relationship between short chain fatty acid and in vitro gas production. J. Agric. Sci. 2003, 139, 341-352. [CrossRef]

32. Bouattour, M.A.; Casals, R.; Albanell, E.; Such, X.; Caja, G. Feeding Soybean Oil to Dairy Goats Increases Conjugated Linoleic Acid in Milk. J. Dairy Sci. 2008, 91, 2399-2407. [CrossRef]

33. Bernard, L.; Leroux, C.; Faulconnier, Y.; Durand, D.; Shingfield, K.J.; Chilliard, Y. Effect of sunflower-seed oil or linseed oil on milk fatty acid secretion and lipogenic gene expression in goats fed hay-based diets. J. Dairy Res. 2009, 76, 241-248. [CrossRef]

34. Kumar, R.; Sivaiah, K.; Reddy, Y.R.; Ekambram, B.; Reddy, T.J.; Reddy, G.V.N. Effect of supplementation of dietary protected lipids on intake and nutrient utilization in Deccani lambs. Trop. Anim. Health Prod. 2006, 38, 151-158. [CrossRef]

35. Kumar, S.; Reddy, Y.R.; Kumari, N.N.; Sridhar, K.; Rao, D.S. In vitro, in situ and in vivo evaluation of straw based diets supplemented with bypass fat as concentrated energy source in Murrah buffaloes. Buffalo Bull. 2017, 36, 357-368.

36. Maia, M.d.O.; Susin, I.; Ferreira, E.M.; Nolli, C.P.; Gentil, R.S.; Pires, A.V.; Mourão, G.B. Intake, nutrient apparent digestibility and ruminal constituents of sheep fed diets with canola, sunflower or castor oils. Rev. Bras. Zootec. 2012, 41, 2350-2356.

37. Nur Atikah, I.; Alimon, A.R.; Yaakub, H.; Abdullah, N.; Jahromi, M.F.; Ivan, M.; Samsudin, A.A. Profiling of rumen fermentation, microbial population and digestibility in goats fed with dietary oils containing different fatty acids. BMC Vet. Res. 2018, 14, 344. [CrossRef] [PubMed] 
38. Vargas-Bello-Pérez, E.; Márquez-Hernández, R.I.; Hernández-Castellano, L.E. Bioactive peptides from milk: Animal determinants and their implications in human health. J. Dairy Res. 2019, 86, 136-144. [CrossRef] [PubMed]

39. Lee, C.; Hristov, A.N.; Heyler, K.S.; Cassidy, T.W.; Long, M.; Corl, B.A.; Karnati, S.K.R. Effects of dietary protein concentration and coconut oil supplementation on nitrogen utilization and production in dairy cows. J. Dairy Sci. 2011, 94, 5544-5557. [CrossRef] [PubMed]

40. Mir, Z.; Goonewardene, L.A.; Okine, E.; Jaegar, S.; Scheer, H.D. Effect of feeding canola oil on constituents, conjugated linoleic acid (CLA) and long chain fatty acids in goats milk. Small Rumin. Res. 1999, 33, 137-143. [CrossRef]

41. Chilliard, Y.; Ferlay, A.; Rouel, J.; Lamberet, G. A Review of Nutritional and Physiological Factors Affecting Goat Milk Lipid Synthesis and Lipolysis1. J. Dairy Sci. 2003, 86, 1751-1770. [CrossRef] [PubMed]

42. Lock, A.L.; Rovai, M.; Gipson, T.A.; de Veth, M.J.; Bauman, D.E. A conjugated linoleic acid supplement containing trans-10, cis-12 conjugated linoleic acid reduces milk fat synthesis in lactating goats. J. Dairy Sci. 2008, 91, 3291-3299. [CrossRef] [PubMed]

43. Lu, C.D. Implication of Feeding Isoenergetic Diets Containing Animal Fat on Milk Composition of Alpine Does During Early Lactation1. J. Dairy Sci. 1993, 76, 1137-1147. [CrossRef]

44. Palmquist, D.L. The Role of Dietary Fats in Efficiency of Ruminants. J. Nutr. 1994, 124, 1377S-1382S. [CrossRef]

45. Storry, J.E.; Hall, A.J.; Johnson, V.W. The effects of increasing amounts of dietary tallow on milk-fat secretion in the cow. J. Dairy Res. 1973, 40, 293-299. [CrossRef]

46. Palmquist, D.L.; Jenkins, T.C. Fat in Lactation Rations1, 2: Review. J. Dairy Sci. 1980, 63, 1-14. [CrossRef]

47. McGuire, M.A.; Bauman, D.E. Milk biosynthesis and secretion. In Encyclopedia of Dairy Science; Roginsky, H., Fuquay, J.W., Fox, P.F., Eds.; Academic Press: New York, NY, USA, 2003; pp. 1828-1834.

48. Christensen, R.A.; Drackley, J.K.; LaCount, D.W.; Clark, J.H. Infusion of four long-chain fatty acid mixtures into the abomasum of lactating dairy cows. J. Dairy Sci. 1994, 77, 1052-1069. [CrossRef]

49. Luna, P.; Bach, A.; Juárez, M.; de la Fuente, M.A. Effect of a Diet Enriched in Whole Linseed and Sunflower Oil on Goat Milk Fatty Acid Composition and Conjugated Linoleic Acid Isomer Profile. J. Dairy Sci. 2008, 91, 20-28. [CrossRef]

50. Ayeb, N.; Addis, M.; Fiori, M.; Khorchani, S.; Atigui, M.; Khorchani, T. Quality and fatty acid profile of the milk of indigenous goats subjected to different local diets in Tunisian arid lands. J. Anim. Physiol. Anim. Nutr. 2016, 100, 101-108. [CrossRef] [PubMed]

51. Liu, J.X.; Susenbeth, A.; Südekum, K.H. In vitro gas production measurements to evaluate interactions between untreated and chemically treated rice straws, grass hay, and mulberry leaves. J. Anim. Sci. 2002, 80, 517-524. [CrossRef] [PubMed]

52. Kurade, M.B.; Saha, S.; Salama, E.S.; Patil, S.M.; Govindwar, S.P.; Jeon, B.H. Acetoclastic methanogenesis led by Methanosarcina in anaerobic co-digestion of fats, oil and grease for enhanced production of methane. Bioresour. Technol. 2019, 272, 351-359. [CrossRef]

53. Vargas-Bello-Pérez, E.; Cancino-Padilla, N.; Romero, J.; Garnsworthy, P.C. Quantitative analysis of ruminal bacterial populations involved in lipid metabolism in dairy cows fed different vegetable oils. Animal 2016, 10, 1821-1828. [CrossRef]

54. Szumacher-Strabel, M.; Cieślak, A.; Nowakowska, A. Effect of oils rich in linoleic acid on in vitro rumen fermentation parameters of sheep, goats and dairy cows. J. Anim. Feed Sci. 2009, 18, 440-452. [CrossRef]

(C) 2020 by the authors. Licensee MDPI, Basel, Switzerland. This article is an open access article distributed under the terms and conditions of the Creative Commons Attribution (CC BY) license (http://creativecommons.org/licenses/by/4.0/). 